\title{
Technology Foresight on Emerging Technologies: Implications for a National Innovation Initiative in Brazil
}

\author{
Maria Fatima Ludovico de Almeida', Carlos Augusto Caldas de Moraes², \\ Maria Angela Campelo de Melo 3
}

\begin{abstract}
Prospective studies about emerging technologies and their implications for public policy formulation indicate critical choices ranging from global to national level, even to the individual firm or institution. Emerging technologies have been shaping the future of some industries and transforming many others. In many cases, these technologies will determine the restructuring of industries as never before. Specially designed for enabling better planning and future decisions, technology foresight (TF) methods are used to foresee diffusion of innovations, mapping out commercially viable roadmaps for technological development. This paper is concerned with a methodological instrument adopted in Brazil as support for building the Agenda for a National Innovation Initiative (NII), which was articulated by government, universities, R\&D institutions, and private firms. It presents and discusses an integrated methodological approach for a TF study, specially designed for the purpose of this Brazilian innovation policy instrument, concerning three emerging technologies - nanotechnology, biotechnology, and information and communication technologies (ICT).
\end{abstract}

Keywords: technology foresight; emerging technologies; national innovation initiative; national innovation system; biotechnology; nanotechnology; information and communication technologies; Brazil.

\footnotetext{
'Center for Science and Technology Pontifical Catholic University of Rio de Janeiro - PUC-Rio Rua Marquês de São Vicente, 225. 22453-900, Rio de Janeiro, RJ, Brazil. Phone: +55 21 3527I542. e-mail: fatima.ludovico@puc-rio.br ${ }_{2}^{2}$ Masters Program in Business Economics and Management Candido Mendes University Rua da Assembleia, $10,3^{\circ}$ andar, sala 319. Centro, Rio de Janeiro 20040-020, Rio de Janeiro, RJ, Brazil. Phone: +55 21 3543-6494. e-mail: caldas.moraes@gmail.com 3Administration Department Pontifical Catholic University of Rio de Janeiro - PUC-Rio. Rua Marquês de São Vicente, 225. 22453-900, Rio de Janeiro, RJ, Brazil. Phone: + 55212138 9313. e-mail: macm@puc-rio.br
}

ISSN: 07 I8-2724. (http://www.jotmi.org) 


\section{Introduction}

Emerging technologies based on biotechnology, nanotechnology and information and communication technologies (ICT) have been shaping the future of some industries and transforming many others. In many cases, these technologies will determine the development and restructuring of industries as never before. These changes, in turn, might promote debates and revisions of current regulatory frameworks and business corporate models towards a vision for a sustainable future. From the perspective of mapping the global future through innovation based on emergent technologies, this paper presents and discusses an integrated methodological approach for technology foresight studies, specially designed for the purpose of a Brazilian innovation policy instrument, concerning three emerging technologies - nanotechnology, biotechnology and information and communication technologies (ICT).

Technology foresight (TF) methods have being used to foresee adoption or diffusion of innovations, mapping out commercially viable roadmaps for technological development. Besides, governments can use national foresight studies to assess the course and impact of technological change and their implications for an effective public policy. From the perspective of employing technology foresight tools to prospect advances of emerging technologies, we considered for the purpose of the research, from which this paper was originated, those methods involving participatory mechanisms, as follows: (i) Delphi technique; and (ii) technology roadmapping, preconizing advances in technologies and markets, in order to define plans and strategic targets for short-, medium- and long-term.
This paper is concerned with a methodological instrument adopted in Brazil as support for building the Agenda for a National Innovation Initiative (NII), which was articulated by government, universities, R\&D institutions, and private firms. We present the conceptual model developed for forecasting the mentioned emergent technological areas and for building the respective future visions towards sustainable development (2025 horizon). The effectiveness of the prospective studies was directly linked to a methodological design established from a precise definition of the questions to be answered, and the careful choice of participants and experts involved, from the three spheres: government, academia and private sector. From this perspective, the methodology encompassed: (i) the definition of technological topics to be studied in each strategic area, based on a detailed analysis of previous studies; (ii) a survey focusing on general questions about the development of each strategic area in Brazil; (iii) a collective building of future vision, including the design of technological and strategic roadmaps, indicating the most promising applications and strategic opportunities for the country; and (iv) the formulation of the NIl's Strategic Agenda, according to six dimensions: human resources, infrastructure, investment, legal/regulatory issues, sociocultural and ethical issues, and market challenges.

Within the context of the National Innovation Initiative (NII), a technology foresight (TF) study was developed by the Center for Strategic Studies and Management in Science, Technology and Innovation (CGEE) for each strategic area, with the general objective of providing the bases for a structured Agenda. This Agenda comprised strategic guidelines and a set of short-, medium- and long-term actions that would support the development of topics associated to each technological group, as depicted in Figure I.

Figure I shows the scope of this TF study on emerging technologies for the Brazilian NII Project. It comprises technological groups, defined for each strategic area (nanotechnology, biotechnology, and ICT), six dimensions of analysis (according to the NII common framework), the sectors most impacted by the development of emergent technologies, and major innovation mobilizing agents government, academia and industry. 


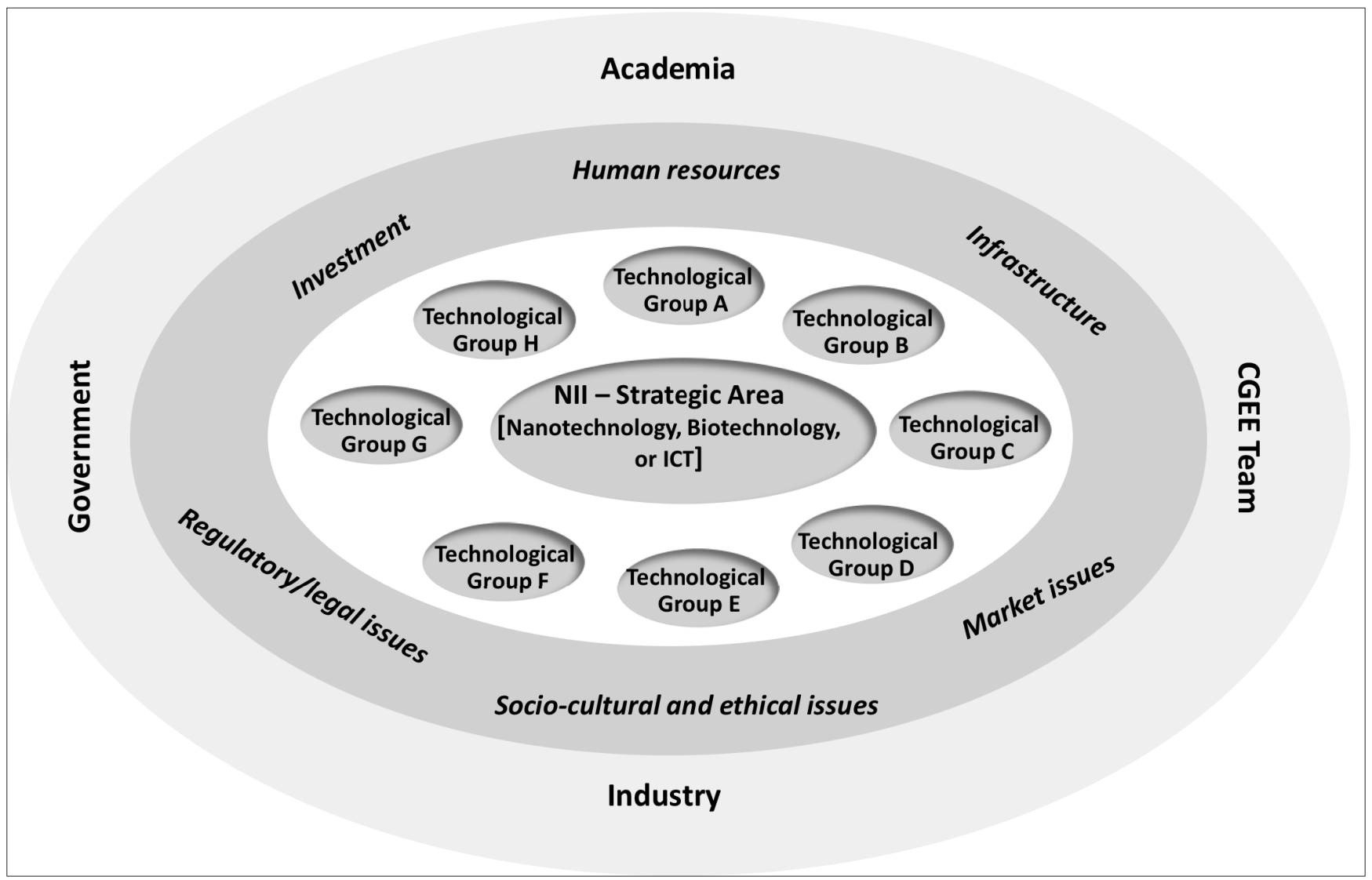

Figure I. Scope of prospective studies on emerging technologies for the Brazilian National Innovation Initiative (NII). 
More specifically, each prospective study for the Brazilian National Innovation Initiative (NII) aimed at: (i) analyzing, for each emerging technology (nanotechnology, biotechnology or ICT), the relevant documents on national innovation policies and strategies, as well as national and international reports on market, regulatory and other aspects; (ii) building a future vision about the development of the technological topics associated to each strategic area in Brazil, starting with the design and analyses of technological and strategic roadmaps, thus allowing for the identification of the most promising applications and the priorities for supporting actions; (iii) defining a current outlook in Brazil concerning the three strategic areas and taking into consideration six analytical dimensions (see Table I); and (iv) developing and validating guidelines and actions proposals that will constitute the NII Agenda for each strategic area. Table I describes the six analytical dimensions considered.

The paper is organized as follows: firstly, to build the foundations for modeling the TF methodological approach, we conceptualize innovation system from different perspectives. Then, a theoretical framework integrating the approaches of innovation system and key TF methodologies is proposed in the context of public policy formulation. Finally, the empirical results concerning three prospective studies coordinated by CGEE are discussed. Focusing on nanotechnology, biotechnology and ICT, they involved (in all) about 180 participants from academic institutions, R\&D centers, industry, and government agencies. The last section presents conclusions and implications for future adoption of the model in other contexts.

\section{Theoretical Background}

The theoretical background encompasses the following themes: (i) technology, knowledge creation and technology planning; (ii) innovation systems; and (iii) technology foresight and two selected prospective tools, namely Delphi technique and technological roadmapping.

\section{Technology, Knowledge Creation and Technology Planning}

A critical analysis of many published definitions of technology (e.g. Floyd, 1997; Whipp, 199I; Steele, 1989) indicates a number of factors that characterize technology, which can be considered as a specific type of knowledge. The characteristics which distinguish technology from more general knowledge types are that it is 'action-oriented' and focuses on the 'know-how' of the organization (Phaal et al., 2000, 2004).

\begin{tabular}{|l|l|}
\hline Dimension & Description \\
\hline Human resources & $\begin{array}{l}\text { Actions to promote education and competence building for the development of S,T\&I in } \\
\text { the NII strategic areas. }\end{array}$ \\
\hline Infrastructure & $\begin{array}{l}\text { Actions to consolidate and expand the physical infrastructure in public and private } \\
\text { technological institutions focusing on the development of RD\&l in industry; to support } \\
\text { greater interaction among businesses and S,T\&l centers; and to promote the creation of } \\
\text { new technology-based firms. }\end{array}$ \\
\hline Investment & $\begin{array}{l}\text { Actions to mobilize the various available financing mechanisms in order to; (i) provide to } \\
\text { new firms adequate sources of financing, including non-reimbursable options and venture } \\
\text { capital/private equity; (ii) to evaluate the use and application of fiscal incentives to indus- } \\
\text { trial innovation and international trade. }\end{array}$ \\
\hline Legal/regulatory issues & $\begin{array}{l}\text { Actions to enhance legal and regulatory aspects that will have direct impact on the } \\
\text { industrial development in order to expedite competitive entry of new technology-based } \\
\text { products and processes in the local or international markets. }\end{array}$ \\
\hline $\begin{array}{l}\text { Socio-cultural and ethical } \\
\text { issues }\end{array}$ & $\begin{array}{l}\text { Actions focusing on the ethical and socio-cultural aspects related to the use of new tech- } \\
\text { nologies in products, services and processes, and their acceptance by the society. }\end{array}$ \\
\hline Market issues & $\begin{array}{l}\text { Actions focusing on the essential elements for the competitive insertion of innovations } \\
\text { generated by Brazilian firms in local and foreign markets. }\end{array}$ \\
\hline
\end{tabular}

Table I.Analytical dimensions for building a National Innovation Initiative (NII) Agenda.

ISSN: 07 I8-2724. (http://www.jotmi.org)

Journal of Technology Management \& Innovation (c) Universidad Alberto Hurtado, Facultad de Economía y Negocios. 
In the business context, technology has been considered as resource for moving firm's operations or as a driver for generating new businesses. Resource-based views of the firm (Grant, 1991), such as core competences (Hamel and Prahalad, 1994) and capability approaches (Teece et al., 1997), have considerable links to technology and knowledge creation (Phaal et al., 2000, 2004).

Assuming technology as is one of the key sources of competitive advantage in business context, technology management plays a crucial role in ensuring that technological resources will be linked to market requirements. From this perspective, Phaal et al. $(2000,2004)$ consider temporal aspects crucial for technology planning, both in terms of internal cycles within the firm (e.g. strategy, budgeting, planning and new product development cycles), as well as external factors (e.g. competitor activities, market changes, and technological developments, government support and regulatory rules, among others factors). With special attention to these issues, they developed a framework based upon the previous work by Andreasen and Hein (1987).

This framework brings together knowledge and resourcebased concepts and focuses on technology planning area in three 'levels':

- 'Business level': the organization and innovation networks, business portfolio, marketing, strategic planning, and financial functions required to create value to the business into the future (Mintzberg, 1994);

- 'Product level': the manufacturing and operations functions, product and service portfolio and platforms, together with innovation and new product development processes (Twiss, 1986);

- 'Technology level': the technology, engineering and science skills and platforms of the organization, together with technology management processes, i.e. identification, selection, acquisition, exploitation and protection of technology (Gregory, 1995).

Effective alignment of technology with business objectives requires effective mechanisms for knowledge flow between the levels, in terms of 'pull' to ensure that business and market requirements are understood at the product and technology levels, and also 'push' to ensure that technological capabilities are understood at the product and business levels. Effective technology management requires an appropriate balance between 'market/product pull' and 'product/technology push'.
Knowledge concepts (e.g. explicit knowledge and tacit knowledge), patterns of creating knowledge, and organizational learning approaches (Argyris and Schön, 1978, 1996; March, 199I; Kim, 1993; Easterby-Smith et al., 2000; Gregory, 1995) are particularly important for effective technology management processes, together with analysis of key 'dimensions' of knowledge, such as 'know-why', 'knowwhat', 'know-how', and 'know-when' (Chai et al., 1999). These dimensions are included in the framework proposed by Phaal et al. $(2000,2004)$. Various types of mechanisms can support learning and knowledge flows across levels, including multidisciplinary teams, staff mobility, communication systems, business processes and management tools.

Examples of such tools include technology foresight, including technology roadmapping and Delphi technique, together with portfolio approaches (e.g. Cooper et al., 1997) and technology valuation methods. As a matter of fact, one firm can only appropriate value from its technological assets and realize the potential competitive advantage if the knowledge that flows between the levels (business, product, and technology) are efficient and effective, creating a technological capability (Grant, 199I). Particularly, technology foresight has received growing attention among those involved in the shaping and implementation of Science, Technology, and Innovation (S,T\&l) policies. Although evaluation of foresight exercises have supplied evidence on relevant benefits, they also point to challenges in translating foresight results into actions, which should be implemented by the government agencies, S\&T institutions, universities and private firms. This issue will be further discussed in this paper.

\section{Innovation systems}

The concept of innovation system has been around for more than 20 years and today it is widely spread among policy makers as well as researchers all over the world (Freeman, 1987; Lundvall, 1992; Edquist and Johnson, 1997; OECD, 1997).

OECD (1997, p. 10) presented several definitions for a national system of innovation as follows:

- ".. the network of institutions in the public and private sectors whose activities and interactions initiate, import, modify and diffuse new technologies." (Freeman, 1987).

- ".. the elements and relationships which interact in the production, diffusion and use of new, and economically useful, knowledge ... and are either located within or rooted inside the borders of a nation state." (Lundvall, 1992). 
- “... a set of institutions whose interactions determine the innovative performance ... of national firms." (Nelson, 1993).

- “. .. the national institutions, their incentive structures and their competencies, that determine the rate and direction of technological learning (or the volume and composition of change generating activities) in a country." (Patel and Pavitt, 1994).

- “.. that set of distinct institutions which jointly and individually contribute to the development and diffusion of new technologies and which provides the framework within which governments form and implement policies to influence the innovation process. As such it is a system of interconnected institutions to create, store and transfer the knowledge, skills and artefacts which define new technologies." (Metcalfe, 1995).

According to Lundvall (1992), there are several new concepts emphasizing the systemic characteristics of innovation with focus at other levels of the economy than the nation state. They are: (i) 'technological systems', in the beginning of the nineties (Carlsson and Stankiewitz, 1995); (ii) regional systems of innovation (Maskell and Malmberg, 1997; Malmberg and Maskell, 2002; Asheim and Gertler, 2004); (iii) sectoral systems of innovation (Breschi and Malerba, 1997; Malerba, 2004); and (iv) triple helix-concept (Etzkowitz and Leydesdorff, 2000).

Considering the objectives of the NII prospective study (focus of this article), we adopted the definition of Lundvall (1992) and agree with these assumptions established by OECD (1997, p. 13):

"For policy makers, an understanding of the national innovation system can help identify leverage points for enhancing innovative performance and overall competitiveness. It can assist in pinpointing mismatches within the system, both among institutions and in relation to government policies, which can thwart technology development and innovation. Countries differ in the way in which knowledge flows are structured and in the relative importance of different types of institutions, actors and linkages for their respective production systems".

Technology and innovation policies pay special attention to the institutional and organizational dimension of innovation systems, including competence building and organizational performance (Lundvall and Borrás, 2006). The relevant and potentially successful technology and innovation policies (adaptive ones), rely on, and learn from, feedback from the selection process to the development of further variation (Metcalfe and Georghiou, 1998).
In other words, policy formulation is increasingly becoming a learning process (Lundvall and Borrás, 1998, 2006). This notion underlines the importance of foresight studies, as in the case focused here. Policies that are more robust can be devised when (i) alternative futures are considered, and (ii) participants with different background are actively involved in a decision-preparatory process, and thus bringing (providing) wide-ranging accumulated knowledge, experience, aspirations, and ideas.

\section{Technology Foresight and Selected TF Tools}

According to a literature review on Technology Foresight (Miles, 2010; Georghiou and Keenan, 2005; Georghiou et al., 2008; Popper, 2008; Phaal et al., 2000, 2004; Keenan et al., 2003), new TF tools and techniques have been developed, promoting an unprecedented diffusion of foresight, planning and participatory approaches to long-term issues. In consequence, prospective approaches are now widely accepted and legitimated.

As posed by Miles (2010), "the concept of technology foresight took off in the 1990s, as European, and then other countries sought new policy tools to deal with problems in their science, technology and innovation systems. Large-scale exercises drew in numerous stakeholders as sources of knowledge and influence, and the prominence of these exercises led to 'foresight' being used much more widely to describe futures activities of many kinds" (Miles, 20 I0, p. 1448).

Technology foresight has been defined as a structured approach for setting priorities for science and technology resource allocation (Keenan et al., 2003), but also as a dialogue process that support Martin and Irvine's (1989) five Cs, as follows: (i) concentration on the long-term horizons; (ii) improved coordination among the stakeholders' visions, intentions, and actions; (iii) consensus on research areas that seem particularly promising; (iv) more intensive communication; and (v) commitment to the implementation of Science, Technology and Innovation (S,T\&I) policies.

Although much of the foresight literature has been concerned with the shaping of S,T\&I policies, foresight is here defined as "a purposefully organized process bringing together expectations of diverse actors about a technology, to formulate strategic views about the future that take into account broad social and economic development" (Webster, 2002, p.5).

The objectives of technological foresight studies is to search for a shared vision of the most important demands and promising fields of research in the future and to establish priorities, but also to articulate diverse actors around the challenges of an uncertain future and its complexity 
constraints, as well as quality of life and society improvements. We selected two Technology Foresight tools to be applied in the context of the Brazilian National Innovation Initiative: (i) Delphi technique; and (ii) technological roadmapping.

The Delphi technique is defined as a structuralized method of indirect and anonymous interaction between specialists by means of questionnaires, disposal of data statistics and control the feedback of the information generated by the consulted specialists (Adler and Ziglio, 1996). Its application in technology planning processes allows overcoming the undesirable effect and the difficulties in the mutual social relations, while preserving the positive aspects of opinion and knowledge diversity. More detailed descriptions on Delphi technique applications in several contexts can be found in the works of Dietz (1987); Rowe et al. (I99I);Adler and Ziglio (1996); and Héraud et al. (1997).
Complementary to Delphi exercises, the participative construction of technology roadmaps, through focused workshops, enables various actors to apprehend organizational knowledge about strategic issues, as well as capture signs of change from the external technological and market environments. Phaal et al. (2004) presents a roadmap generic model, integrating the approaches of innovation ('technology push' and 'market pull') and indicating the aspects of 'know-why', 'know-what', 'knowhow' and 'know-when', conceived by Chai et al. (1999), as depicted in Figure 2.

The building process allows for the systematization of this knowledge under those aspects, later helping to identify bottlenecks and critical areas of decision-making along the trajectories drawn on maps in technology (Figure 2). Besides integrating the two approaches of innovation ('technology push' and 'market pull'), this framework indicates the four aspects considered by Chai et al. above mentioned. Detailed discussion on theoretical and practical issues of this TF tool can be found in works by Barker and Schmidt (1995); Groenveld (1997); Kappel (1998, 200I); Phaal et al. (2000, 2004); Albright and Kappel (2003); and Winebrake (2004).

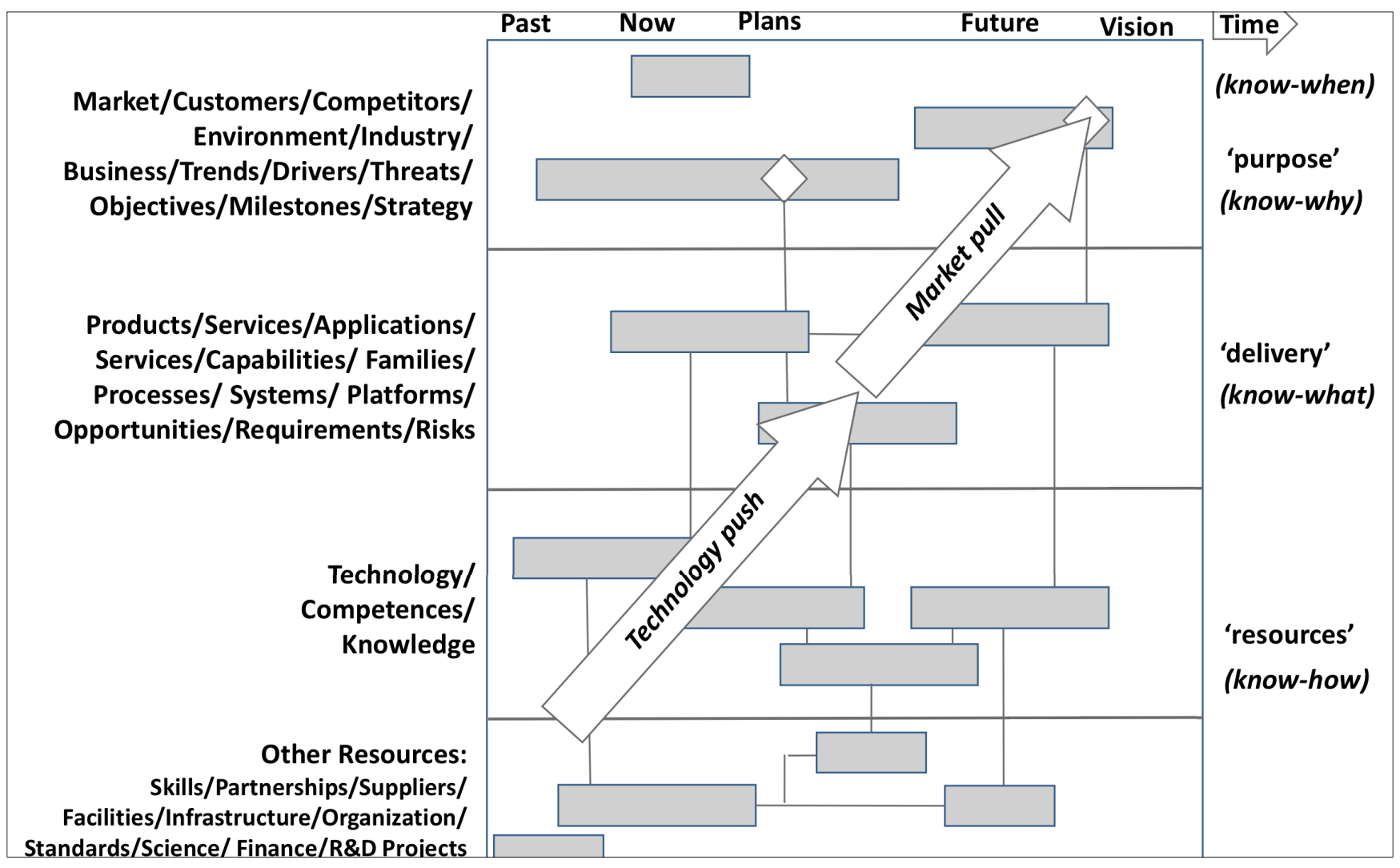

Figure 2. Generalized technology roadmap architecture. Source: Phaal et al. (2003). 


\section{Methodological Instrument Developed for NII Project}

In this section, we present a brief description of the methodological instrument developed for the NII Project, and the specific issues of the application context, covering the strategic areas considered, namely nanotechnology, biotechnology and ICT. They are considered emergent technologies shaping the future of several industrial and services sectors in a sustainable way. Complementing the theoretical background, we present conceptual approaches selected for the construction of strategic and technological roadmaps, as well as its graphical representation. For the analysis of impacts and limitations on future development of selected 'technological groups' (see Figure I) concerning each strategic area in Brazil, research tools were designed and applied during the TF workshops focused on the development of sectors based on these emergent technologies.

The research methodology proposed for the collective construction of the Strategic Area's Vision of a Sustainable Future: 2025 horizon (considering biotechnology, nanotechnology or ICT as enablers or drivers) comprises the following steps: (i) definition of the topics to be analyzed, after a critical review of previous reports on each strategic area published by CGEE, and also by international institutions; (ii) structured query, based on Delphi technique, regarding the market and regulatory drivers of business affected by technological advances on these three strategic areas (See Figure I); (iii) collective construction of a vision of the future (2025 horizon), comprising the design of technological roadmaps of portfolios of each strategic area (two maps - one for world state-of-art and the second for Brazilian potential developments; and (iv) proposal of actions to be included in the NII Agenda (nanotechnology, biotechnology and ICT), according to the six analytical dimensions shown in Table I.

In particular, for the construction of technology roadmaps, the conceptual model proposed by Phaal et al. $(2000,2004)$ guided the design of the maps schematically depicted in Figures 3 and 4. These roadmaps were built through participative workshops involving representatives of industry, academy and government, i.e., the main stakeholders of the National Innovation Initiative Project. The CGEE's Project Team coordinated all workshops in order to apply the same methodological framework to the three strategic areas (nanotechnology, biotechnology, and ICT). Generally, the construction of the roadmaps begins with a workshop directed to the upper layers of Figure 2, which are associated to 'market and products/services' dimensions ('marketpull'). After this, the roadmap is completed in another workshop, which focuses on the lower layers of the roadmap ('technology-push'). In this second event, technology trajectories are anticipated and a set of actions required to support the development of new processes, products and markets are proposed. Figure 3 illustrates a customized technology roadmap adopted during the workshops.

\begin{tabular}{|c|c|c|c|c|}
\hline \multirow[b]{3}{*}{$\underset{\uparrow}{\text { Market }}$} & \multirow{2}{*}{ Stages } & \multicolumn{3}{|c|}{ Technological Roadmap [title]: Brazil or World } \\
\hline & & 2008-2010 & 2011-2015 & 2016-2025 \\
\hline & Commercialization & \multicolumn{3}{|c|}{ Capacity of commercialization in large scale } \\
\hline & Production & \multicolumn{3}{|c|}{ Capacity of production in large scale with new technology embedded } \\
\hline & $\begin{array}{l}\text { Innovation/ } \\
\text { process or } \\
\text { product }\end{array}$ & \multicolumn{3}{|c|}{$\begin{array}{l}\text { Productive sectors with capacity of embedding R\&D results in new } \\
\text { processes, products or services, and introducing innovations to the } \\
\text { market }\end{array}$} \\
\hline $\begin{array}{l}\text { Science \& } \\
\text { Technology }\end{array}$ & $\begin{array}{l}\text { Research and } \\
\text { Development }\end{array}$ & \multicolumn{3}{|c|}{ Capacity of scientific and technological development } \\
\hline
\end{tabular}

Figure 3. Conceptual template for technology roadmapping in the context of NII Project in Brazil.

ISSN: 07 I8-2724. (http://www.jotmi.org)

Journal of Technology Management \& Innovation (c) Universidad Alberto Hurtado, Facultad de Economía y Negocios. 
It is worth mentioning that, in the design phase of the methodology, a few adjustments had to be made on the generic model of Figure 2, in order to meet some relevant aspects of the specific context of the NII Project.

The representation of technological maps (the same for both maps - Brazil and World), with the respective topics associated with the applications of emerging technologies in a particular industry, is presented in Figure 4. The associated topics are listed in this figure with alphanumerical references. Its market and technological trajectories were designed during the prospective exercise, according to the developments expected to occur over time (2025 horizon).
The prospective exercise included the identification of decision points in the schematic representations of Brazilian technology roadmaps, that means, points that require actions to support the achievement of the vision of the future represented by trajectories of the topics under discussion. The conceptual framework adopted for the construction of the technological roadmaps, as mentioned earlier, was based on a referential approach developed by the Centre for Technology Management, University of Cambridge, England. The steps concerning the analysis of social and economic impacts of technologies and the construction of the strategic research development and innovation portfolio (RD\&l) are based on the model of assessment of sustainability of technologies, proposed by Almeida (2006). This model has been adopted by a large Brazilian energy company, particularly by its R,D\&l function, and has already been used in prospective studies published by CGEE.

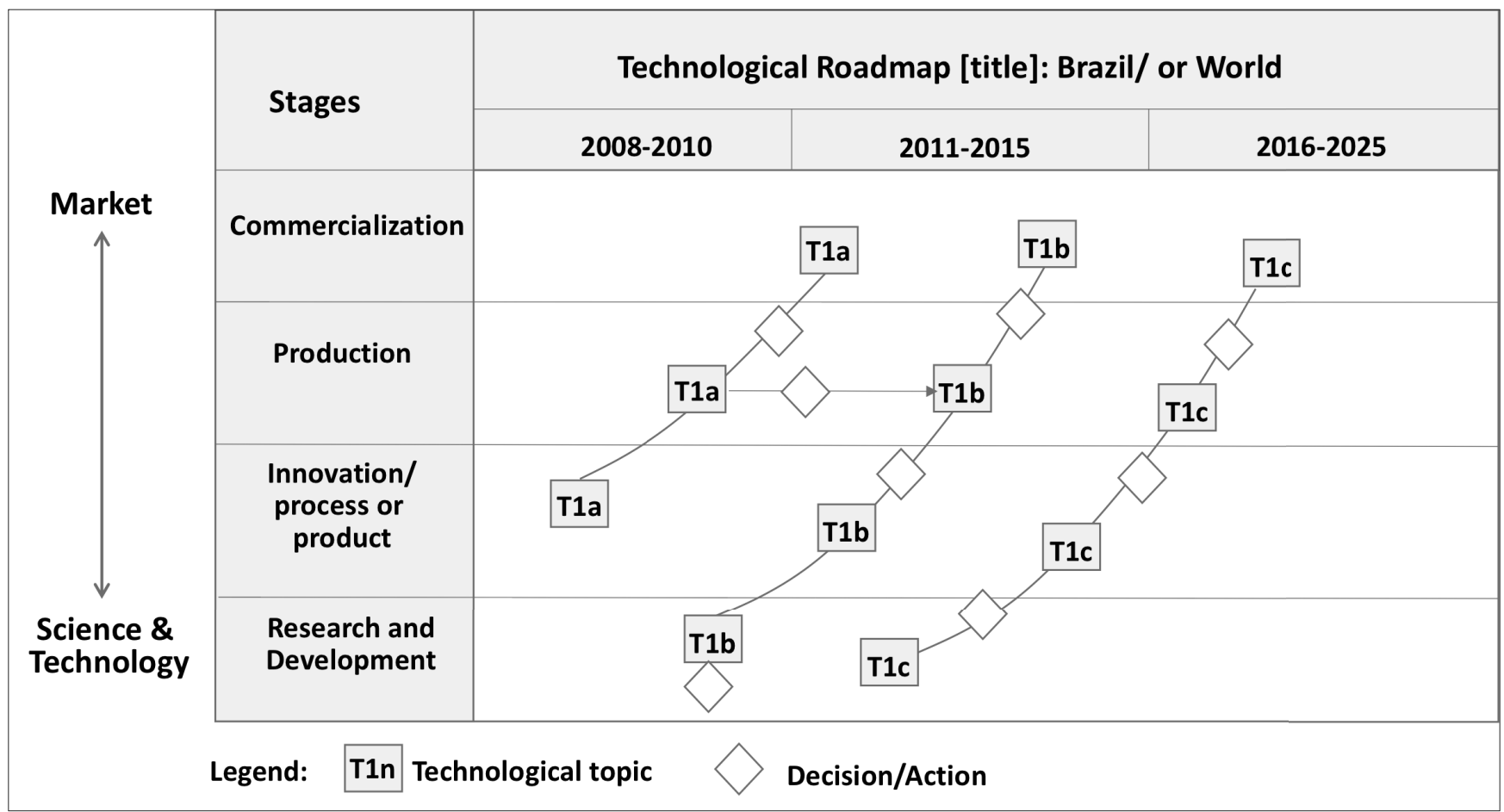

Figure 4. Schematic representation of a technology roadmap customized for NII project in Brazil. 
The strategic portfolio represents graphically the synthesis of the results of the strategic analysis of technologies, and must be constructed plotting the technologies examined, according to two axes: (i) sustainability, resulting from the evaluation of the social and economic impacts of each technology; and (ii) degree of effort required for the materialization of respective technological trajectories, considering the efforts necessary for human resources capacitation, consolidation of physical infrastructure, investments, setting/reviewing regulations regarding clean production feasibility and competitive and sustainable marketing/distribution. Its graphical representation can be seen in Figure 5.

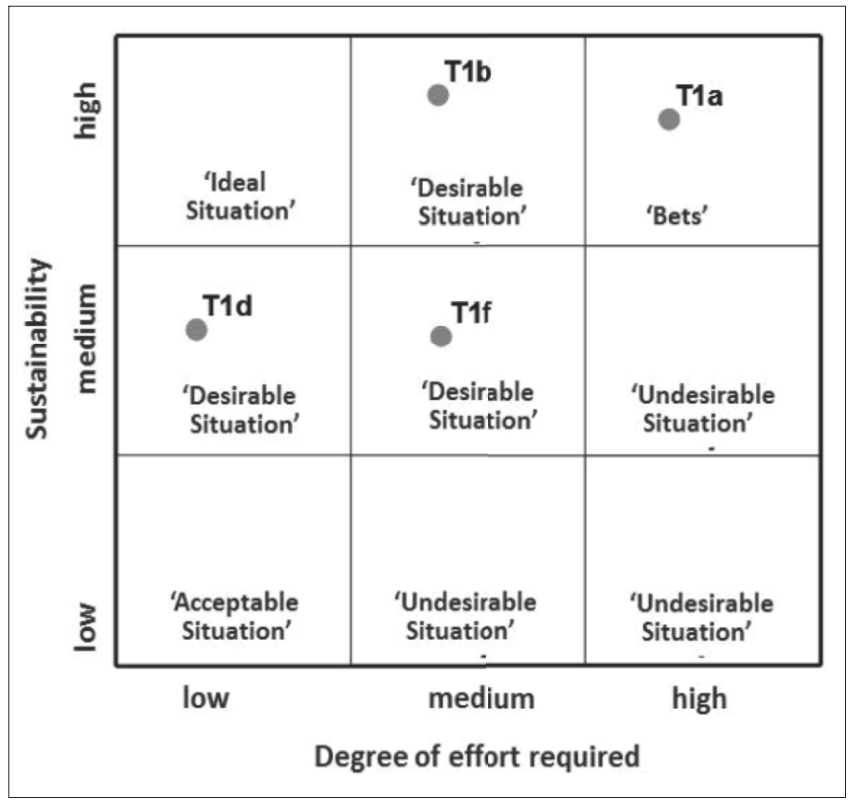

Figure 5. Schematic representation of strategic R,D\&I portfolio customized for NII project in Brazil.

Thus, for each dimension of analysis and temporal horizon, a set of actions have been proposed to support the trajectories of topics preconized in the Brazilian technology roadmaps. These actions were directly linked to the decision points marked in the respective roadmaps, according to the six analytical dimensions shown in Table I.

Finally, it is important mentioning that the effectiveness of a prospective study is directly linked to a methodological design with a precise delimitation of the questions to be answered, a systematization of processes, a careful choice of participants and specialists involved, and an evaluation of the process (by milestones), that allows course corrections with a view to their improvement as a whole.

\section{Results}

The main findings of the CGEE project, according to the steps of the proposed TF methodology can be synthetized as follows:

- $\quad 177$ technological topics were consensually selected, after a critical review of previous CGEE's reports on each strategic area, and also of external references;

- six technological roadmaps and three strategic R,D\&l portfolios concerning for each strategic area nanotechnology, biotechnology, and ICT;

- $\quad$ proposals for short-, medium-, and log-term actions to be included in the NII Strategic Agenda, focusing on the six dimensions considered: human resources; infrastructure; investment; regulatory/legal issues; societal and ethical issues; and market aspects.

The technological roadmaps and the S,T\&l strategic portfolios developed by experts from university, industry, and government allowed the identification of the most promising innovation opportunities for the country, according to two criteria: (i) sustainability, calculated from the economic, social and environmental impacts resulting from future applications; and (ii) degree of effort required to achieve the position defined in the technological roadmap for Brazil, that should consider existing barriers, uncertainties, and technological and commercial risks.

From this structured process of analysis, it was possible to spot applications considered strategic for the country in different levels: (a) 72 'bets', related to those topics having high sustainability, but requiring intense effort, in most cases due to their embryonic stage; (b) 10 in 'ideal situation', related to those topics having high sustainability and requiring less effort, on a comparative basis; (c) 78 in 'desirable situation', i.e. when topics have high sustainability, but their development would require an average degree of effort; (d) 13 in 'acceptable situation', related to those topics having, on a comparative basis, average sustainability and requiring an average degree of effort, in most cases through partnerships and international cooperation; and (e) 4 topics classified in "undesirable situation", which were not considered as object of NII Strategic Agenda.

The methodological approach adopted in the studies required multiple reciprocal relationships during the prospective workshops, especially in the occasion of identification of supporting actions required to achieve the desired position defined in respective technological roadmaps (regarding Brazil), for each of the six dimensions considered. 
Table 2. Main findings of TF activities supporting the formulation of a NII Strategic Agenda.

\begin{tabular}{|c|c|c|c|c|c|c|c|}
\hline Strategic area & Technology roadmaps & Strategic R,D\&I portfolios & & & & & \\
\hline & Technological groups & Topics & Bets & $\begin{array}{l}\text { Desirable } \\
\text { situation }\end{array}$ & $\begin{array}{l}\text { Acceptable } \\
\text { situation }\end{array}$ & \begin{tabular}{|l|} 
Ideal \\
situation
\end{tabular} & $\begin{array}{l}\text { Undesirable } \\
\text { situation }\end{array}$ \\
\hline \multirow[t]{6}{*}{ Nanotechnology } & Nanomaterials & 8 & 4 & 4 & - & - & - \\
\hline & Nanoeletronics & 8 & 3 & 5 & - & - & - \\
\hline & Nanophotonics & 9 & 3 & 6 & - & - & - \\
\hline & Nanobiotechnology & 8 & 2 & 5 & - & I & - \\
\hline & Nanoenergy & 9 & 4 & 5 & - & - & - \\
\hline & Nano environment & II & 7 & 3 & - & I & - \\
\hline Subtotal & 6 & 53 & 23 & 28 & 0 & 2 & 0 \\
\hline \multirow[t]{5}{*}{ Biotechnology } & Health and Medicine applications & 9 & 6 & 3 & - & - & - \\
\hline & Biopharmaceuticals & 21 & 7 & 13 & - & 1 & - \\
\hline & Agroindustry applications & 8 & 5 & 3 & - & - & - \\
\hline & Biofuels and other energy applications & 15 & 10 & 2 & - & 3 & - \\
\hline & Environmental applications & 11 & 4 & 6 & - & 1 & - \\
\hline Subtotal & 5 & 64 & 32 & 27 & 0 & 5 & 0 \\
\hline \multirow[t]{7}{*}{ ICT } & $\begin{array}{l}\text { Convergent telecommunications ser- } \\
\text { vices }\end{array}$ & 8 & 1 & 3 & 3 & - & 1 \\
\hline & Interactive digital TV & 10 & I & 3 & 3 & - & 3 \\
\hline & Systems applied to public safety & 9 & 3 & 3 & 3 & - & - \\
\hline & Systems applied to human health & 4 & 1 & 3 & - & - & - \\
\hline & $\begin{array}{l}\text { Systems applied to energy and the } \\
\text { environment }\end{array}$ & 10 & 2 & 6 & 1 & 1 & - \\
\hline & $\begin{array}{l}\text { Traceability systems for animals, food } \\
\text { and wood }\end{array}$ & 12 & 2 & 5 & 3 & 2 & - \\
\hline & Systems applied to navigability & 7 & 7 & - & - & - & - \\
\hline Subtotal & 7 & 60 & 17 & 23 & 13 & 3 & 4 \\
\hline Total & 18 & 177 & 72 & 78 & 13 & 10 & 4 \\
\hline
\end{tabular}

Table 2 summarizes the main results of TF activities supporting the formulation of a NII Strategic Agenda. 
For each dimension (e. g. legal/regulatory issues), representatives of academia, industry, and government had to consider their individual (and institutional) traditional functions and also 'the roles of others', since we employed the technique of cross-fertilization of ideas.

It is important to note that the threeTF studies resulted from a collective endeavor, involving a total of 180 participants, representing academic institutions, R\&D centers, industries and government agencies that were related to the different fields in the focused technological areas. Based on the results of these studies, and with the commitment of all participants, the 'Strategic Agenda' for the implementation of the NII concerning the three areas - nanotechnology, biotechnology, and ICT - could be established.

\section{Conclusions}

This work aimed to present a methodology for building the future vision (2025 horizon) and for formulating a Strategic Agenda concerning Brazilian NII Project (focusing on nanotechnology, biotechnology and ICT areas). The methodology, based upon two selected TF methods, encompassed an application of Delphi technique, for filling up the upper layers of respective technological roadmaps, and technology roadmapping per se, developed in workshops carried out for each focus area (that corresponded to the three emergent technologies).

Considering the quality outcomes from these prospective workshops, we can say that the conceptual model adopted in TF exercises was appropriate for the intended purposes: to foresee emergent technological areas, through technology roadmapping and use of Delphi technique, to prioritize $R$, D\&l efforts in these areas in Brazil in a systemic way, with the support of strategic technological portfolios (Figure 5), and to build the respective future visions towards sustainable development (2025 horizon). The effectiveness of these prospective studies confirmed the importance of a proper methodological design established from a precise definition of the questions to be answered, and the careful choice of participants and experts involved, from the three spheres: government, academia and private sector.

Noteworthy are the following differentials of the methodological design in relation to current practice of TF studies concerning emergent technologies. More precisely:

- $\quad$ Linking of direct supporting actions that are part of their strategic agendas for the implementation of the National Innovation Initiative with the trajectories of technological and market related topics, in the horizons established;
- Inclusion of social and environmental criteria for assessing the impacts of the focused technologies and building strategic R,D\&l portfolios (sustainability versus degree of R,D\&l effort);

- Construction of technological roadmaps in one single workshop event (by strategic area), enhanced by the employment of the technique of cross-fertilization of ideas. The main findings of the three prospective studies reinforced that there are certain sector- and technology-specific patterns of innovation to be taken into account in public policies and corporate strategies aligned to a vision for a sustainable future. It was assumed that the evolution of these sectors based on the diffusion of emergent technologies would have a great impact on the achievement of the vision for a sustainable future in 2025 .

The TF exercises developed during the workshops have produced several important insights that are useful for developing public policy programs intended to stimulate and support innovations concerning biotechnology, nanotechnology, and ICT prospects. They could help companies to establish their corporate strategies, and also academic institutions to define their R,D\&l strategic orientation. The 'technology roadmaps' and 'R,D\&I technology portfolios' highlighted how a sustainable future can be supported or driven by emergent technologies, considering social, economic, and political forces, and how decision-makers could be provided with relevant information to their future strategic choices. 


\section{References}

ADLER, M., Ziglio, E. (1996). Gazing into the oracle. Jessica Kingsley Publishers, Bristol.

ALBRIGHT, R. E., Kappel, T. A. (2003). Roadmapping in the corporation. Research Technology Management, 46, 3I-40.

ALMEIDA, M. F. L. (2006). Sustentabilidade corporativa, inovação tecnológica e planejamento adaptativo: dos princípios à ação. 259 p. Doctoral Dissertation (Production Engineering). Industrial Engineering Department. Pontifical Catholic University - Rio de Janeiro.

ANDREASEN, M., Hein, M.L. (1987). Integrated product development. Springer-Verlag IFS Ltd, London.

ARGYRIS, C., Schön, D. (1978). Organizational learning: a theory of action perspective. Addison-Wesley, Reading.

ARGYRIS, C., Schön, D. (I996) Organizational learning II: theory, method and practice.Addison-Wesley, Reading.

ASHEIM, B., Gertler, M. (2004). Understanding regional innovation systems. In: Fagerberg, J.; Mowery, D. C.; Nelson, R. R. (Eds.), The Oxford handbook of innovation. Oxford Press, New York. pp. 23I-3I7.

BARKER, D., Smith, D.J. H. (I995). Technology foresight using roadmaps. Long Range Planning, 28(2), 2I-28. doi: http:// dx.doi.org/I0.10I6/0024-630I(95)98586-H

BRESCHI, S., Malerba, F. (I997). Sectoral innovation systems: technological regimes, Schumpeterian dynamics, and spatial boundaries. In: Edquist, C. (Ed.). Systems of innovation: technologies, institutions and organizations. Pinter, London and Washington. Pp. I30-I52.

CARLSSON, B., Stankiewicz, R. (1995). On the nature, function and composition of technological systems. In: Carlsson, B. (Ed.), Technological systems and economic performance: the case of factory automation. Kluwer Academic Publishers, Dordrecht. pp. 2I-56.

CENTRE FOR TECHNOLOGY MANAGEMENT. Roadmapping - resources. University of Cambridge. 2012. Retrieved March 12, 2015, from http://www.ifm.eng.cam. ac.uk/ctm/trm/resources.html.

CHAl, K. H., Shi, Y. J., Gregory, M. J. (1999). Bridging islands of knowledge: a framework of knowledge sharing in international manufacturing networks. In: 6th European Operations Management Annual Conference, Venice. Pp. I-I5.
COOPER, R. G., Edgett, S. J., Kleinschmidt, E. J. (1997). Portfolio management for new products, Addison-Wesley, Reading.

DIETZ, T. (1987). Methods for analyzing data from Delphi panels: some evidence from a forecasting study. Technological Forecasting and Social Change, 3I(I), 79-85. doi:I0.1016/0040-I625(87)90024-2

EASTERBY-SMITH, M., Crossan, M., Nicolini, D. (2000). Organizational learning: debates past, present and future. Journal of Management Studies, 37(6), 783-796. doi: |0.1 II |/|467-6486.00203

EDQUIST, C. (1997). Systems of innovation: technologies, institutions and organizations. Pinter Publishers, London.

EDQUIST, C., Johnson, B. (1997). Institutions and organizations in systems of innovation. In: Edquist, C. (Ed.), Systems of innovation: technologies, institutions and organizations. Pinter Publishers, London. 23 pp.

ETZKOWITZ, H., Leydesdorff, L. (2000). The dynamics of innovation: from national systems and 'mode 2' to triple helix of university-industry-government relations, Research Policy, 29 (2), I09-123. doi: I 0.1016/0040-1625(87)90024-2

FLOYD, C. (1997). Managing technology for corporate success, Aldershot, Gower.

FREEMAN, C. (1987). Technology policy and economic performance: lessons from Japan. Pinter Publishers, London.

GEORGHIOU, L., Keenan, M. (2005). Evaluation of national foresight activities: assessing rationale, process and impact. Technology Forecasting and Social Change, 73 (7), 76I-777. doi: 10.1016/j.techfore.2005.08.003

GEORGHIOU, L., Cassingena, J., Keenan, M., Miles, I., Popper, R. (Eds.), The handbook of technology foresight, Edward Elgar, Cheltenham.

GRANT, R. M. (|99|). The resourced-based theory of competitive advantage: implications for strategy formulation. California Management Review, 33(3), I I4- I 35. doi: |0.2307/4 | 666664

GREGORY, M. J. (1995). Technology management: a process approach. Journal of Engineering Manufacture, 209 (5), 347356. doi: 10.1243/PIME_PROC_1995_209_094_02

GROENVELD, P. (1997). Roadmapping integrates business and technology, Research-Technology Management, 40 (5), 48-55. 
HAMEL, G., Prahalad, C. K. (1994). Competing for the future, Harvard Business School Press, Boston.

HÉRAUD, J. A., Munier, F., Nanopoulos, K. (1997). Méthode Delphi: une étude de cas sur les technologies du futur. Futuribles, 218, 33-53.

KAPPEL,T.A. (1998). Technology roadmapping: an evaluation. $\mathrm{PhD}$ dissertation. Northwestern University.

KAPPEL, T. A. (200I). Perspectives on roadmaps: how organizations talk about the future. Journal of Product Innovation Management, I8(I), 39-50.

KEENAN, M., Miles, I., Koi-Ova, J. (2003). Handbook of knowledge society foresight. European Foundation for the Improvement of Living and Working Conditions, Dublin. Retrieved March 12, 20I5, from http://foretech.online.bg/ docs/EFL_Handbook_October.pdf.

KIM,D. (1993). The link between individual and organizational learning. Sloan Management Review, Fall 1993, 37-50.

LUNDVALL, B-A (1992). National systems of innovation: towards a theory of innovation and interactive learning. Pinter Publishers, London.

LUNDVALL, B-A., Borrás, S. (1998). The globalizing learning economy:implications for innovation policy. Office for Official Publications of the European Communities, Luxembourg.

LUNDVALL, B-A., Borrás, S. (2006). Science, technology and innovation policy. In: Fagerberg, J.; Mowery, D. C.; Nelson, R. R. (Eds.), The Oxford handbook of innovation. Oxford Press, New York. pp. 599-93I.

MALERBA, F. (Ed.) (2004). Sectoral systems of innovation: concepts, issues and analyses of six major sectors in Europe. Cambridge University Press, 2004, Cambridge.

MALMBERG, A., Maskell, P. (2002). The elusive concept of localization economies: towards a knowledge-based theory of spatial clustering. Environment and Planning, 34, 429-449. doi: 10.1068/a3457

MARCH, J. G. (1991). Exploration and exploitation in organizational learning. Organizational Science, 2(I), 34-45.

MARTIN, B., Irvine, J. (1989). Research foresight. Edward Elgar, Aldershot.
MASKELL, P., Malmberg, A. (1997). Towards an explanation of regional specialization and industry agglomeration. European Planning Studies, 5(I), 25-4I. doi:I0.1080/096543 | 9708720382

METCALFE, S. (1995). The economic foundations of technology policy: equilibrium and evolutionary perspectives. In: Stoneman, P. (Ed.), Handbook of the economics of innovation and technological change. Blackwell Publishers, Oxford Press, Cambridge. pp. 409-512.

METCALFE, S. J., Georghiou, L. (1998). Equilibrium and evolutionary foundations of technology policy, STI Review, 22, 75-100. doi: 10.1787/sti_rev-v1998-I-en

MILES,Y. (2010). The development of technology foresight: a review. Technological Forecasting and Social Change, 77(9), |448- | 456. doi: I0.1016/0040-I625(91)90039-|

MINTZBERG, H. (1994).The rise and fall of strategic planning, The Free Press, New York.

NELSON, R. R. (Ed.) (1993). National innovation systems: a comparative study. Oxford University Press, New York/ Oxford.

NELSON, R. R.,Winter, S. G. (1982). An evolutionary theory of economic change. Belknap Press, Cambridge.

ORGANISATION FOR ECONOMIC CO-OPERATION AND DEVELOPMENT. OECD (1997). National innovation systems. OECD Publications, Paris.

PATEL, P., Pavitt, K. (1994). The nature and economic importance of national innovation systems". STI Review, 14, 9-32. OECD, Paris.

PHAAL, R., Farrukh, C. J. P., Probert, D. R. (2000). Fast-start technology roadmapping. White Paper. Department of Engineering, University of Cambridge, CB2 IRX, UK. 2000, Cambridge.

PHAAL, R., Farrukh, C.J.P., Mitchell, R., Probert, D.R. (2003). Starting-up roadmapping fast. Research Technology Management, 46 (2), 52-58.

PHAAL, R., Farrukh, C.J.P., Probert, D. R. (2004). Customizing roadmapping. Research Technology Management, 47 (2), 2637.

POPPER, R. (2008) Foresight methodology. In: Georghiou, L., Cassingena, J., Keenan, M., Miles, I., Popper, R. (Eds.), The handbook of technology foresight, Edward Elgar, Cheltenham, pp. 44-88. 
ROWE, G.,Wright, G., Bolger, F.(I99I). Delphi:a reevaluation of research and theory. Technological Forecasting and Social Change, 39(3), 235-25I. doi:I0.1016/0040-1625(91)90039-I

STEELE, L. W. (1989). Managing technology - the strategic view. McGraw-Hill, New York.

TEECE, D. J., Pisano, G., Shuen,A. ( 1997). Dynamic capabilities and strategic management. Strategic Management Journal, I8(7), 509-533. doi: 10.1002/(SICl) I097-0266(I99708)

TWISS, B. (1986). Managing technological innovation. 3rd ed. Pitman Publishing, New York.

WEBSTER,A. (2002). Foresight as a tool for the management of knowledge flows. Report for EC STRATA Workshop, Brussels, 22-23 April 2002.

WHIPP, R. (199I). Managing technological changes: opportunities and pitfalls. International Journal of Vehicle Design, I 2 (5/6), 469-477. doi: I0. I504/IJVD. 1991.061693

WINEBRAKE, J. (2004). Technology roadmaps as a tool for energy planning and policy decisions. Energy Engineering, I0I(4), 20 - 36. doi: I0.1080/0199859040950927I 